\title{
PENGENALAN INTERNET DAN JARINGAN PADA SISWA SMAN 1 AIR JOMAN
}

\author{
Febri Dristyan $^{1}$, Herman Syahputra ${ }^{2}$, Gunawan Syahputra ${ }^{3}$ \\ ${ }^{1,2,3}$ Sisem Informasi, STMIK royal Kisaran \\ email: fdristyan@royal.ac.id
}

\begin{abstract}
Community Service Activities in the form of internet and network training in SMA Negeri 1 Air Joman aims to increase students' knowledge of network technology and the benefits of internet and encourage students to be able to independently manage network and internet. The training method used is the form of training in the classroom by using lecture, discussion and question and answer methods as well as network practice directly. The lecture method used is intended to provide a theoretical explanation of internet and network material. Discussion methods are used to explore students understanding of the material given in the lecture. Practice method is used to show directly how to make a network cable. Benefits derived from this training activity is the students are able to make a network connection with cable and know the benefits of the internet.
\end{abstract}

Keywords: Internet, Networking, Community Service, students

\begin{abstract}
Abstrak: Kegiatan Pengabdian Pada Masyarakat berupa pelatihan internet dan jaringan di SMA Negeri 1 Air Joman bertujuan untuk meningkatkan pengetahuan siswa terhadap teknologi jaringan dan manfaat dari internet serta mendorong siswa agar mampu dengan mandiri mengelola jaringan dan internet. Metode pelatihan yang digunakan adalah bentuk pelatihan di dalam kelas dengan menggunakan metode ceramah, diskusi dan Tanya jawab serta praktek jaringan secara langsung. Metode ceramah yang digunakan dimaksudkan untuk memberikan penjelasan secara teori terhadap materi internet dan jaringan. Metode diskusi digunakan untuk menggali pemahaman siswa terhadap materi yang diberikan secara ceramah. Metode praktek digunakan untuk menunjukan langsung cara membuat kabel jaringan. Manfaat yang diperoleh dari kegiatan pelatihan ini adalah siswa mampu membuat koneksi jaringan dengan kabel serta mengetahui manfaat dari internet.
\end{abstract}

Kata kunci:Internet, Jaringan, PKM, siswa

\section{PENDAHULUAN}

Seiring dengan kemajuan
pengetahuan dan teknologi
komputerisasi, lebih khusus
perangkat lunak, maka baik
langsung maupun tidak
pendidikan juga menuai dampaknya.
Siswa sebagai bibit penerus generasi
bangsa dituntut untuk mengikuti

perkembangan teknologi dan informasi. Selama ini cara pembelajaran secara tatap muka masih memiliki beberapa kelemahan. Salah satunya adalah perbedaan dari setiap murid dalam menangkap dan mencerna materi pembelajaran. Ada murid yang mengerti, ada yang kurang mengerti, bahkan ada yang tidak mengerti sama sekali. Oleh karena itu, internet memiliki peranan 
Vol. 1, No. 2, Jul 2018, hlm. $81-86$

ISSN 2614-7912 (cetak)

ISSN 2622-3813 (online)

Available online at http://jurnal.stmikroyal.ac.id/index.php/jurdimas

penting dalam hal ini, yaitu dapat membantu mengatasi permasalahan dan kelemahan yang ada. Internet dapat membantu siswa mendapatkan ilmu dari luar sekolah, sehingga proses pembelajaran dapat berjalan dengan baik serta siswa dapat menangkap dan mencerna materi yang diajarkan oleh Guru

\section{METODE}

Materi pengabdian kepada masyarakat disusun sesuai dengan tujuan yang ingin dicapai diantaranya mengenai pengenalan jaringan Internet, budaya internet, manfaat internet serta undang undang penggunaan internet.

Metode pelaksaan dalam pengabdian masyarakat ini adalah dengan cara melaksanakan kegiatan pelatihan dalam bentuk presentasi, dengan menjelaskan dasar teori dan praktek langsung.

\section{PEMBAHASAN}

Jaringan Komputer adalah sekelompok komputer otonom yang saling berhubungan antara satu dengan lainnya menggunakan protokol komunikasi melalui media komunikasi sehingga dapat saling berbagi informasi, programprogram, penggunaan bersama perangkat keras seperti printer, harddisk,dan sebagainya. Selain itu jaringan komputer bisa diartikan sebagai kumpulan sejumlah terminal komunikasi yang berada diberbagai lokasi yang terdiri dari lebih satu komputer yang saling berhubungan.

Tujuan dibangunya suatu jaringan komputer adalah membawa informasi secara tepat dan tanpa adanya kesalahan dari sipengirim (transmitter) menuju kesisi penerima (receiver) melalui media komunikasi.

Ada beberapa hal yang masih dirasa menjadi kendala, yaitu:

1. Masih mahalnya fasilitas komunikasi yang tersedia dan bagaimana memanfaatkan jaringan komunikasi yang ada secara efektif dan efisien.

2. Jalur transmisi yang digunakan tidak benar-benar bebas dari masalah gangguan (noise).

Manfaat yang didapat dalam membangun jaringan komputer, yaitu:

1. Sharing resources

Sharing resources bertujuan agar seluruh program, peralatan atau peripheral lainnya dapat dimanfaatkan oleh setiap orang yang ada pada jaringan komputer tanpa terpengaruh oleh lokasi maupun pengaruh dari pemakai.

2. Media Komunikasi

Jaringan komputer memungkinkan terjadinya komunikasi antar pengguna, baik untuk teleconference maupun untuk mengirim pesan atau informasi yang penting lainnya.

3. Integrasi Data

Jaringan komputer dapat mencegah ketergantungan pada komputer pusat, karena setiap proses data tidak harus dilakukan pada satu komputer saja, melainkan dapat didistribusikan ke tempat lainnya. Oleh sebab inilah maka dapat terbentuk data yang terintegrasi yang memudahkan pemakai untuk memperoleh dan mengolah informasi setiap saat.

4. Pengembangan dan Pemeliharaan Pengembangan peralatan dapat dilakukan dengan mudah dan menghemat biaya, karena setiap pembelian komponen seperti printer, maka tidak perlu membeli printer sejumlah komputer yang ada tetapi cukup satu buah karena printer itu dapat digunakan secara bersama-sama. Jaringan komputer juga memudahkan pemakai dalam merawat harddisk dan peralatan lainnya, misalnya untuk memberikan perlindungan terhadap serangan virus maka pemakai cukup memusatkan perhatian pada harddisk yang ada pada komputer pusat.

5. Keamanan Data

Sistem Jaringan Komputer dapat memberikan perlindungan terhadap data. Karena pemberian dan pengaturan 
Vol. 1, No. 2, Jul 2018, hlm. $81-86$

ISSN 2614-7912 (cetak)

ISSN 2622-3813 (online)

Available online at http://jurnal.stmikroyal.ac.id/index.php/jurdimas

hak akses kepada para pemakai, serta teknik perlindungan terhadap harddisk sehingga data mendapatkan perlindungan yang efektif.

6. Sumber Daya Lebih Efisien dan Informasi Terkini

Dengan pemakaian sumber daya secara bersama -sama, akan mendapatkan hasil yang maksimal dan kualitas yang tinggi. Selain itu data atau informasi yang diakses selalu terbaru, karena setiap ada perubahan yang terjadi dapat segera langsung diketahui oleh setiap pemakai.

Berdasarkan jarak dan area kerjanya jaringan komputer dibedakan menjadi tiga kelompok,yaitu:

1. Local Area Network(LAN)

Local Area Network (LAN), merupakan jaringan milik pribadi di dalam sebuah gedung atau kampus yang berukuran sampai beberapa kilometer. LAN seringkali digunakan untuk menghubungkan komputer-komputer pribadi dan workstation dalam kantor suatu perusahaan atau pabrik-pabrik untuk memakai bersamas umber daya (resouce, misalnya printer) dan saling bertukar informasi.

2. Metropolitan Area Network(MAN)

Metropolitan Area Network(MAN), pada dasarnya merupakan versi LAN yang berukuran lebih besar dan biasanya menggunakan teknologi yang sama dengan LAN. MAN dapat mencakup kantor-kantor perusahaan yang letaknya berdekatan atau juga sebuah kota dan dapat dimanfaatkan untuk keperluan pribadi (swasta) atau umum. MAN mampu menunjang data dan suara,bahkan dapat berhubungan dengan jaringan televisi kabel.

3. Wide AreaNetwork(WAN)

Wide AreaNetwork (WAN)jangkauannya mencakup daerah geografis yang luas, seringkali mencakup sebuah negara bahkan benua. WAN terdiri dari kumpulan mesin-mesin yang bertujuan untuk menjalankan program-program (aplikasi) pemakai.

\begin{tabular}{|c|c|c|}
\hline $\begin{array}{l}\text { Distance } \\
\text { Between CPUs }\end{array}$ & $\begin{array}{l}\text { Location } \\
\text { of CPUs }\end{array}$ & Name \\
\hline $0.1 \mathrm{~m}$ & $\begin{array}{l}\text { Printed circuit board } \\
\text { Personal data asst. }\end{array}$ & $\begin{array}{l}\text { Motherboard } \\
\text { Personal Area Network (PAN) }\end{array}$ \\
\hline $1.0 \mathrm{~m}$ & $\begin{array}{l}\text { Milimeter } \\
\text { Mainframe }\end{array}$ & Computer Systems Network \\
\hline $10 \mathrm{~m}$ & Room & $\begin{array}{l}\text { Local Area Network (LAN) } \\
\text { Your classroom }\end{array}$ \\
\hline $100 \mathrm{~m}$ & Building & $\begin{array}{l}\text { Local Area Network (LAN) } \\
\text { Your school }\end{array}$ \\
\hline $\begin{array}{l}1000 \mathrm{~m}= \\
1 \mathrm{~km}\end{array}$ & Campus & $\begin{array}{l}\text { Local Area Network (LAN) } \\
\text { Stanford University }\end{array}$ \\
\hline $\begin{array}{l}100,000 \mathrm{~m}= \\
100 \mathrm{~km}\end{array}$ & Country & $\begin{array}{l}\text { Wide Area Network (WAN) } \\
\text { Cisco Systems, Inc. }\end{array}$ \\
\hline $\begin{array}{l}1,000,000 \mathrm{~m}= \\
1,000 \mathrm{~km}\end{array}$ & Continent & $\begin{array}{l}\text { Wide Avea Network (WAN) } \\
\text { Africa }\end{array}$ \\
\hline $\begin{array}{l}10,000,000 \mathrm{~m}= \\
10,000 \mathrm{~km}\end{array}$ & Planet & $\begin{array}{l}\text { Wide Area Network (WAN) } \\
\text { The Internet }\end{array}$ \\
\hline $\begin{array}{l}100,000,000 \mathrm{~m}= \\
100,000 \mathrm{~km}\end{array}$ & $\begin{array}{l}\text { Earth-moon } \\
\text { system }\end{array}$ & $\begin{array}{l}\text { Wide Area Network (WAN) } \\
\text { Earth and artificial satellites }\end{array}$ \\
\hline
\end{tabular}

Gambar 1. Tabel WAN

\section{Langkah Membuat Kabel Straight Dan Cross Kabel straight}

Kabel straight merupakan kabel yang memiliki cara pemasangan yang sama antara ujung satu dengan ujung yang lainnya.Kabel straight digunakan untuk menghubungkan 2 device yang berbeda.Urutan standar kabel straight adalah seperti dibawah ini yaitu sesuai dengan standar TIA/EIA 368B (yang paling banyak dipakai) atau kadangkadang juga dipakai sesuai standar TIA/EIA 368A sebagai berikut:

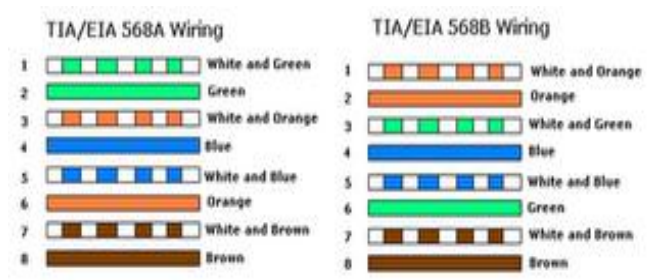

Gambar 2. Kabel Straight

Kabel Cross Over

Kabel cross over merupakan kabel yang memiliki susunan berbeda antara ujung satu denganujung dua. Kabel cross over digunakan untuk menghubungkan 2 device yang sama. Gambar dibawah adalahsusunan standar kabel cross over. 
Vol. 1, No. 2, Jul 2018, hlm. $81-86$

ISSN 2614-7912 (cetak)

Available online at http://jurnal.stmikroyal.ac.id/index.php/jurdimas
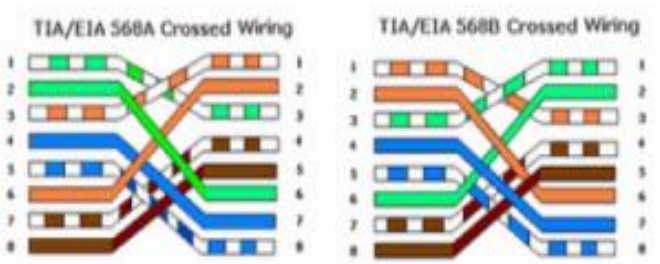

Gambar 3. Kabel Cross Over

Dari 8 buah kabel yang ada pada kabel UTP ini (baik pada kabel straight maupun cross over) hanya 4 buah saja yang digunakan untuk mengirim dan menerima data, yaitu kabel pada pin no 1,2,3 dan 6. Untuk membuat sebuah kabel jaringan di perlukan beberapa peralatan diantaranya :

1. Tang crimping

2. Alat pengupas kabel

3. Kabel UTP

4. Conector RJ-45

5. LAN tester

Langkah-Langkah Pemasangan Kabel UTP

Tipe Straight

Langkah 1 :

Kupas terlebih dahulu ujung kabel menggunakan alat pengupas kabel sekitar kurang lebih $2 \mathrm{~cm}$ sampai kabel yg terdapat di dalam nya terlihat

Langkah 2 :

Pisahkan kabel-kabel tersebut dan luruskan, susunlah kabel-kabel tersebut dengan rapih berdasarkan warna seperti Orange Putih, Orange, Hijau Putih, Biru, Biru Putih, Hijau, Coklat Putih, dan Coklat

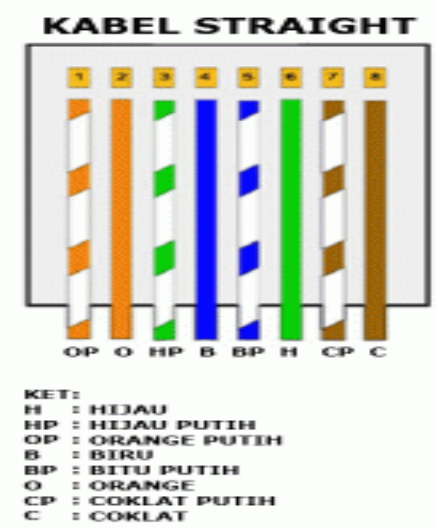

Gambar 4. Urutan Warna Kabel Straight
Langkah 3 :

Setelah kabel tersusun, kemudian ambil Connector RJ-45, Connector ini terdiri dari 8 pin. Pin 1 dari connector ini adalah pin yang berada paling kiri

Langkah 4 :

Masukkan kabel-kabel tersebut hingga bagian ujungnya mentok di dalam Connector dan sesuaikan dengan urutan :

- Orange Putih pada Pin 1

- Orange pada Pin 2

- Hijau Putih pada Pin 3

- Biru pada Pin 4

- Biru Putih pada Pin 5

- Hijau pada Pin 6

- Coklat Putih pada Pin 7

- Coklat pada Pin 8

Langkah 5 :

Setelah selesai menyusun kabel straight kemudian kita akan mencoba dengan menggunakan LAN tester masukkan ujung kabel ke alatnya, kemudian nyalakan, kalau lampu led yang pada LAN tester menyala semua, dari nomor 1 sampai 8 berarti Anda telah sukses.

Langkah 6 :

Untuk cara pemasangan kabel yang kedua, langkah-langkahnya sama dengan pemasangan ujung kabel pertama. Ulangi langkah-langkah tadi untuk memasang connector RJ-45 pada ujung kabel yang kedua.

Tipe Cross

Langkah 1 :

Cara pemasangan kabel UTP tipe cross hampir sama dengan casa pemasangan kabel UTP tipe straight. Hanya saja perbedaan terdapat pada urutan warna kabel pada ujung kabel yang keduanya. Untuk ujung kabel pertama susunan warna pada kabel cross

- Orange Putih pada Pin 1

- Orange pada Pin 2

- Hijau Putih pada Pin 3

- Biru pada Pin 4

- Biru Putih pada Pin 5

- Hijau pada Pin 6

- Coklat Putih pada Pin 7 
Vol. 1, No. 2, Jul 2018, hlm. 81 - 86

Available online at http://jurnal.stmikroyal.ac.id/index.php/jurdimas

- Coklat pada Pin 8.

Setelah selesai menyusun kabel cross kemudian kita akan mencoba dengan menggunakan LAN tester masukkan ujung kabel ke alatnya, kemudian nyalakan. Susunan warna ujung kabel pertama berbeda dengan unjung kabel kedua. Nanti jika dites menggunakan LAN tester, maka nantinya led 1, 2, 3 dan 6 akan saling bertukar.

Dibawah ini merupakan dokumentasi kegiatan pengabdian masyarakat.
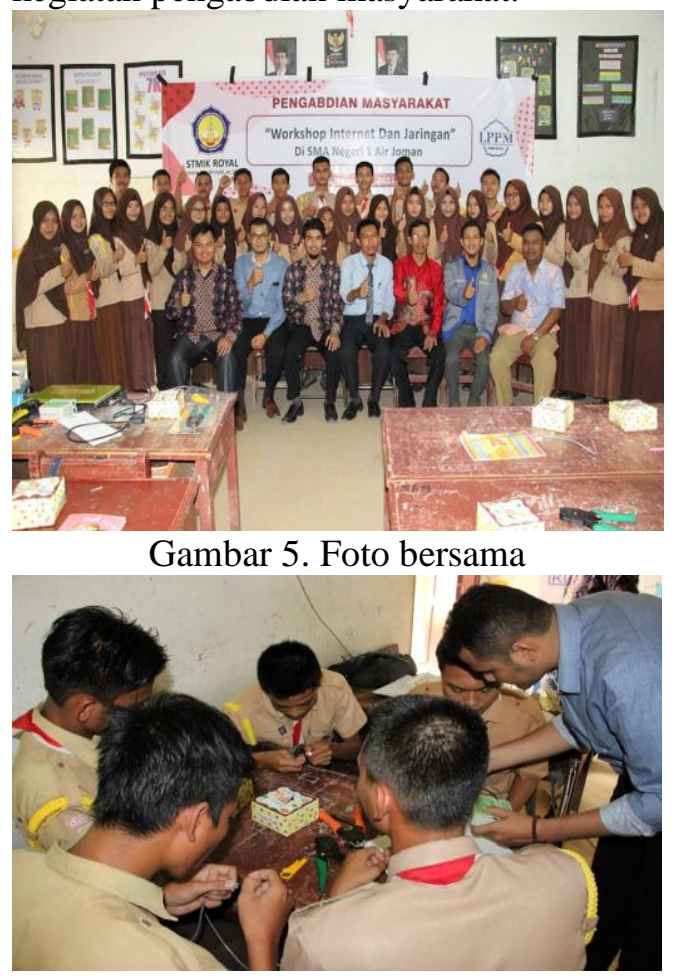

Gambar 6. Pratikum Konfigurasi Kabel

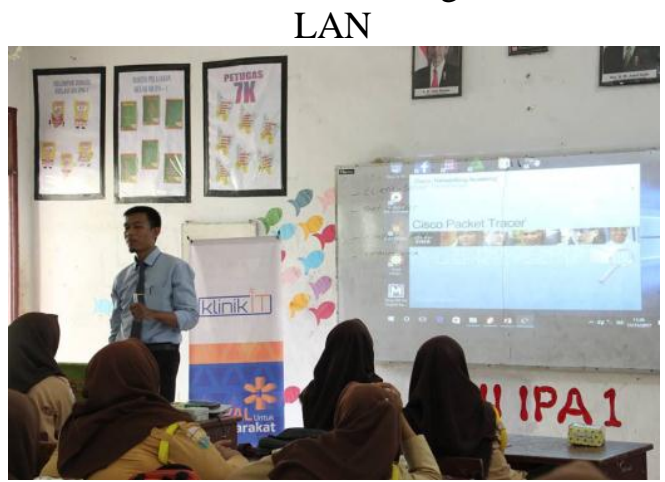

Gambar 7. Penyampaian Materi Oleh Nara Sumber

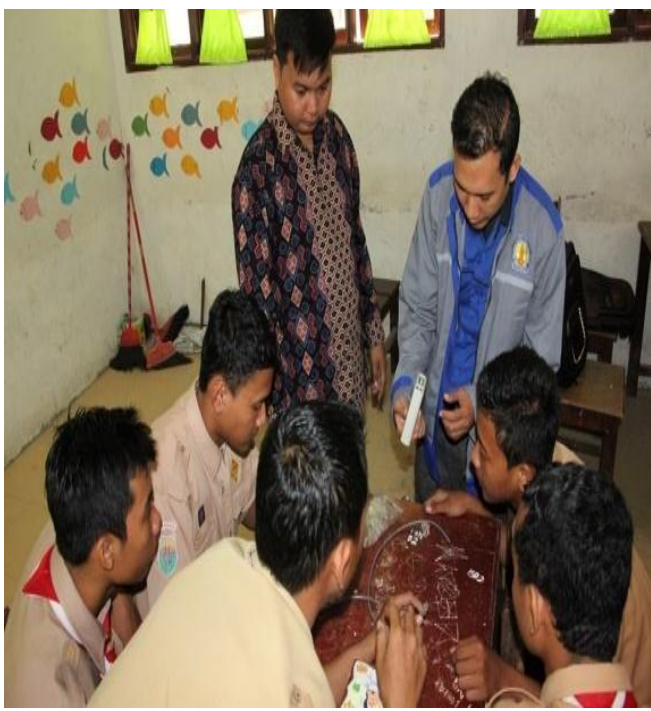

Gambar 8. Pratikum Konfigurasi Kabel LAN

\section{SIMPULAN}

Dari pembahasan bab sebelumnya, kegiatan pengabdian masyarakat ini dapat disimpulkan:

1. Pengabdian kepada masyarakat dilakukan di SMAN 1 Air Joman oleh dosen STMIK Royal Kisaran dengan judul "Internet dan Jaringan".

2. Tujuan dan manfaat dari kegiatan ini sudah tepat sasaran. Sehingga bekal ilmu tentang manfaat dan bahaya internet serta mengenai jaringan dapat di implementasikan dalam mendukung kegiatan belajar siswa.

3. Ada dua sesi yang dilakukan pada kegiatan ini, yaitu penyampaian materi dan sesi praktek. Pada sesi praktek peserta dibantu oleh instruktur untuk memudahkan peserta lebih memahami pengkabelan dan konfigurasi.

\section{UCAPAN TERIMA KASIH}

Kegiatan pengabdian kepada masyarakat ini tidak terlepas dari kerjasama dan bantuan materi, tenaga, dan fikiran dari berbagai pihak. Untuk itu, Tim pengabdian kepada masyarakat mengaturkan ucapan terima kasih kepada: 
Vol. 1, No. 2, Jul 2018, hlm. 81 - 86

ISSN 2614-7912 (cetak)

Available online at http://jurnal.stmikroyal.ac.id/index.php/jurdimas

1 Bapak Anda Putra Lubis, SE., MMA, Ketua Yayasan Royal Teladan Asahan, sebagai penyandang dana,

2) Kepala Sekolah SMAN 1 Air Joman, sebagai mitra kegiatan pengabdian kepada masyarakat,

3) Tim pengabdian kepada masyarakat yang telah bekerjasama dengan baik, sehingga kegiatan dapat berjalan lancar dan sukses.

\section{DAFTAR PUSTAKA}

Rini Agustina, S.Kom, M.Pd, (2015), Internet Sehat dan Aman, Jakarta

Syafrizal, M. (2005). Pengantar jaringan komputer. Penerbit Andi.

Sritrusta Sukaridhoto, ST. Ph.D, (2014), Buku Jaringan Komputer I, Surabaya : Politeknik Elektronika Negeri Surabaya

Wahana Komputer, (2010), Cara Mudah Membangun Jaringan dan Internet, Jakarta : Mediakita 